\title{
Resistance of Capsicum annuum genotypes against various isolates of Phytophthora capsici from Java, Indonesia
}

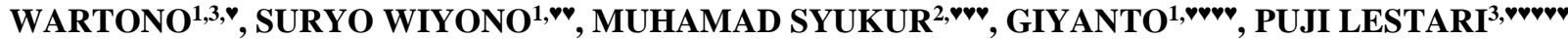 \\ ${ }^{1}$ Department of Plant Protection, Faculty of Agriculture, Institut Pertanian Bogor. Jl. Raya Dramaga, Kampus IPB Darmaga, Bogor 16680, West Java,

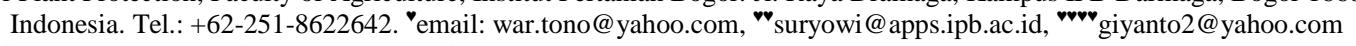 \\ ${ }^{2}$ Department of Agronomy and Horticulture, Faculty of Agriculture, Institut Pertanian Bogor. Jl. Raya Dramaga, Kampus IPB Darmaga, Bogor 16680, \\ West Java, Indonesia. Tel.: +62-251-8622642. "rvemail: muhsyukur@yahoo.com \\ ${ }^{3}$ Indonesian Center for Agricultural Biotechnology and Genetic Resources Research and Development. Jl. Tentara Pelajar No. 13, Bogor 16124, West \\ Java, Indonesia. Tel.: +62-251-8337975, ^vv»email: plestari129@yahoo.com
}

Manuscript received: 15 October 2019. Revision accepted: 25 November 2019.

\begin{abstract}
Wartono, Wiyono S, Syukur M, Giyanto, Lestari P. 2019. Resistance of Capsicum annuum genotypes against various isolates of Phytophthora capsici from Java, Indonesia. Biodiversitas 20: 3723-3730. Phytophthora capsici Leonian is one of the pathogenic oomycetes that can reduce chilli production worldwide. In this study, Indonesian local chilli genotypes were evaluated for their resistance to P.capsici on chilli in Java, under controlled conditions. P. capsici used in this study consisted of four isolates derived from chilli plants in Java Island. The chilli genotypes tested were 38 local chilli (Capsicum annuum L.) originated from Indonesia and 3 introduced $C$. апnиum. Inoculation was carried out by drenching $5 \mathrm{ml}$ suspension of zoospore $\left(1 \times 10^{4}\right)$ on the growing medium suitable for the oomycetes around the plant. Disease symptom was measured at 21 days after inoculation. Salicylic acid and $\beta-1.3$-glucanase analyses were conducted to 7-week old plant with specific interval. Molecular characterization to complement disease assay was carried out using SCAR primers (OpD04,717-F/D04,717-R). Significant differences were found in genotypes, isolates, and interactions between chilli genotypes x P. capsici isolates. Four tested isolates had different levels of virulence ranging from moderate (CpnsCK1, KdrRM3, WnsbCk) to high (WnsbCK2). The chilli genotypes revealed high partial resistance to $P$. capsici, as demonstrated by six genotypes resistant to CpnsCK1, two genotypes to KdrRM3, and one genotype resistant to WnsbCK1. Resistance of one of chilli pepper, Ungara was positively associated with an increase of salicylic acid and $\beta-1.3$-glucanase. There is no association between the SCAR marker with resistance of chilli to $P$. capsici suggested these pathogens from Java are probably controlled by another locus which is not detected by this SCAR marker.
\end{abstract}

Keywords: 717-F/D04,717-R, genotype, interaction, OpD04, resistance, virulence

\section{INTRODUCTION}

Chilli productivity in Indonesia is approximately 7.8 tons/ha (Direktorat Jenderal Hortikultura 2019). However, it is still far below the potential yield which should be reached about 20 tons/ha (Syukur et al. 2010a). One of the factors causing the low production of chilli is diseases caused by $P$. capsici. This pathogen can cause yield reduction up to $65-100 \%$ with losses up to billions of dollars (Oelke et al. 2003).

Phytophthora capsici is a destructive pathogen to chilli pepper (Capsicum annuum L.) worldwide that attacks all tissues and plant growth stages and can cause considerable yield losses (Lamour et al. 2012). This pathogen causes several disease syndromes on pepper plants such as rotted root, blighted stem, blighted foliar, and rotted fruit (Candole et al. 2010). This pathogen seriously affects crop productivity, annual supply, and price stability. The disease is managed by crop rotation, cultural practices, fungicides, and resistant cultivars (Café-Filho and Ristaino 2008; Glosier et al. 2008; Candole et al. 2010). However, application of chemical control is limited and made resistance to fungicides (Café-Filho and Ristaino 2008). While, the use of resistant cultivars is the most effective and viable control method with a low environmental impact.

Plant breeding for resistant cultivar is difficult and complex, especially with the existence of physiological races. Recently, multiple physiological races of Phytophthora have been reported (Glosier et al. 2008; Oelke et al. 2003; Sy et al. 2008). The existence of two different mating types both $\mathrm{A} 1$ and $\mathrm{A} 2$ found in the same field and would increase the probability of sexual recombination leading to the emergence of new races (Sy et al. 2008). The two different mating types were also found in the same field of chilli pepper in Indonesia (Wartono et al. Unpublished). Commercial chilli cultivars which are completely resistant to multiple races of $P$. capsici, particularly in Indonesia, however, have not been available. Therefore, it is needed to breed high resistant chilli to counter various races of $P$. capsici.

To increase chili productivity along with disease resistance can be done through breeding to improved varieties (Syukur et al. 2010b). To develop diseaseresistant chilli plants, identification of genetic resources with high resistance to $P$. capsici is important. Intra and/or interspecies or wild relative species are potential for parental lines. Recently, chilli germplasms have been 
available worldwide across many genebanks, but the potential resistance to $P$. capsici has not been much known. In order to increase the genetic materials of this plant with high value, selection of various chilli genotypes needs to be done to explore chili genotypes resistant to $P$. capsica. According to Syukur et al. (2011) selection will be effective if the population has wide genetic diversity and high heritability.

Time-limited conventional plant breeding is made easy by the presence of molecular markers. Marker-assisted selection (MAS) has been proposed for many years to facilitate breeding of complex traits such as the resistance to $P$. capsici in pepper. The use of molecular markers to identify resistant alleles makes an important contribution to breeding activities (Da Silva et al. 2003). Unlike morphological and biochemical markers, the advantage of molecular marker is not influenced by environmental factors and planting practices (Ovesna et al. 2002). Thus, it is able to simplify and accelerate the selection process. One of the molecular markers that can be used to select important characters in plants is the SCAR (sequence characterized amplified region).

SCAR (sequence characterized amplified region) is a specific molecular marker that is easy to use, effective and reproducible (Kiran et al. 2010; Abidin et al. 2012). This marker is useful in plant breeding, especially for selecting certain characters, such as resistance to pathogen. Kamaluddin et al. (2014) used SCAR marker to discriminate resistant and susceptible genotypes of spring wheat (Triticum aestivum L. em Thell) to stripe or yellow rust of wheat caused by the fungus Puccinia striiformis Westend f. sp. tritici. In previous study, a SCAR marker has been developed to detect resistance to $P$. capsici, this marker was Phyto.5.2 precisely on chromosome 5 of chili pepper, a QTL linked to resistance (Quirin et al. 2005). This study aimed to evaluate the resistance of local chilli pepper genotypes to different $P$. capsici isolates and their molecular analysis using SCAR marker.

\section{MATERIALS AND METHODS}

\section{Plant materials and microbes}

A total of 41 chilli genotypes Capsicum annuum consisting of 38 local genotypes from Indonesia and three introduced genotypes were in this study (Table 1). For pathogenicity evaluation, four 4 isolates of $P$. capsici originally isolated from chilli in the endemic areas of this pathogen in Java were tested their virulence. These four isolates used were CpnsCK1, WnsbCK1, WnsbCK2, and KdrRM3. This evaluation was conducted in both greenhouse and laboratory of the Indonesian Center for Agricultural Biotechnology and Genetic Resources Research and Development from December 2018 until May 2019.

\section{Inoculation and greenhouse assay on resistance of chilli genotype to $P$. capsici}

Five-days-old seeds that have been germinated on wet filter paper were planted in a 50-hole pot tray $4.8 \mathrm{~cm} \times 2.3$ $\mathrm{cm} \times 5 \mathrm{~cm}$ in size containing a mixture of compost, soil and husk charcoal (1: 1: 1). To improve growth, seven days old seedlings were fertilized with $\mathrm{AB}$ mix. The twenty days old seedlings were transplanted to an $8 \mathrm{~cm} \times 7 \mathrm{~cm} \times 9 \mathrm{~cm}$ plastic pot with hollow bottom containing of same cultivation media. Plants were watered every day and $A B$ mix fertilizer was applied at 14 days after transplanting. Four $P$. capsici isolates (KdrRM3, WnsbCK1, CpnsCK1, and WnsbCK2) were prepared for inoculum source. Plug of $P$. capsici from eight-days old mycelia was cultured in 15 $\mathrm{ml}$ of $30 \%$ mungbean extract and incubated at $25^{\circ} \mathrm{C}$ for 3 days. Subsequently, mycelia were washed with sterile water to remove the remaining extract and re-incubated at $25^{\circ} \mathrm{C}$ for the next 3 days under light of a fluorescent lamp (15 watts, Phillip). Zoospores were harvested by adding 20 $\mathrm{ml}$ of water to the petri dish and left for 1 hour at room temperature. Observations were made under a lighted microscope to ensure zoospore release. The concentration of zoospores was determined with a density of 2000 zoospores/ml (Bosland and Lindsey 1991). The inoculation was carried out at 7 weeks-old-seedling by drenching the growing medium with $5 \mathrm{ml}$ of inoculum suspension. As a control, chilli plants were only drenched by $5 \mathrm{ml}$ of sterile water. Seedling on inoculated and control treatment were placed inside a humidity chamber made of $0.1 \mathrm{~mm}$ plastic sheets that were also used to cover the bottom of the greenhouse benches. The wet gunny sacks were overlaid above the plastic chamber and greenhouse benches to keep moist conditions. A factorial experiment was arranged in Completely Randomized Design with 10 replications.

Disease symptom observation was performed at 3, 6, 9, $12,15,18$, and 22 days after inoculation (dai). The disease index (DI) was calculated by the equation of DI $=(\Sigma$ (ni.vi/N.V) x 100, with DI = disease index, ni = number of infected plants on the $i$-th score, vi $=$ the $i$-th score value, $\mathrm{N}$ $=$ number of plants observed, and $\mathrm{V}=$ highest score. Disease score followed the method of Glosier et al. (2008), i.e. $0=$ healthy plant; $1=$ leaf slightly yellowing, but no necrosis on the stem; $2=$ minor necrosis on the stem; $3=$ moderate necrosis on the stems and plant slightly withering; $4=$ severe necrosis and clearly visible plant withering; and $5=$ dead plant. The resistance classification followed the model of Jo et al. (2014), namely resistant (R) (DI < 20), moderately resistant (MR) $(20<\mathrm{DI}>50)$ and susceptible (S) (DI > 50). Analysis of variance was performed using the general linear model (GLM) procedure in the SAS software. The main effects of genotypes and isolates, as well as their interactions, were determined. Genotype $\times$ isolate interaction effects were sliced by isolate in the SAS software in order to identify the specificity of chilli genotypes to particular isolate.

Tabel 1. List of 41 Capsicum annuum genotypes observed in this study 


\begin{tabular}{llc}
\hline \multicolumn{1}{c}{ Genotypes } & Type of chilli & $\begin{array}{c}\text { Country of } \\
\text { origin }\end{array}$ \\
\hline Anies & Curly & Indonesia \\
Ayesha & Ornament & Indonesia \\
Ayesha 2 & Ornament & Indonesia \\
Ayesha Ungu & Ornament & Indonesia \\
Bara & Bird pepper & Indonesia \\
C5 & Red chilli & Indonesia \\
Cakri Andalas & Curly & Indonesia \\
Ciko & Red chilli & Indonesia \\
CL-4 & Bird pepper & Indonesia \\
CM334 & Red chilli & Mexico \\
F5 Syak x 320-201-1-1 & Ornament & Indonesia \\
F5 Syak x 320-202-2-1 & Ornament & Indonesia \\
F5 Syak x 320-202-2-2 & Ornament & Indonesia \\
F6 145291-10-7-1-1-1 & Bird pepper & Indonesia \\
F8 145291-115-8-1-1 & Bird pepper & Indonesia \\
F8 145318-1-1-1-1-3-1 & Ornament & Indonesia \\
F8 160291-3-12-5-4-51-1 & Bird pepper & Indonesia \\
F8 160291-9-4-3-2-1-1 & Bird pepper & Indonesia \\
Genie & Bird pepper & Indonesia \\
Giant A & Red chilli & Argentina \\
Jalapeno & Red chilli & Mexico \\
Kencana & Curly & Indonesia \\
Landung & Red chilli & Indonesia \\
Laris & Curly & Indonesia \\
Lembang 1 & Curly & Indonesia \\
Lembayung & Ornament & Indonesia \\
Lingga & Red chilli & Indonesia \\
Lokal Lembang & Curly & Indonesia \\
Namira & Ornament & Indonesia \\
Nazla & Ornament & Indonesia \\
Rama & Bird pepper & Indonesia \\
Seloka-5 & Red chilli & Indonesia \\
Sempurna & Red chilli & Indonesia \\
SSP & Curly & Indonesia \\
Tanjung-2 & Red chilli & Indonesia \\
Ungara & Ornament & Indonesia \\
Viola & Ornament & Indonesia \\
Violeta & Ornament & Indonesia \\
Violeta 1 & Ornament & Indonesia \\
Vitra & Curly & Indonesia \\
Yuni & Curly & Indonesia \\
\hline & & \\
& & \\
\hline
\end{tabular}

(5\% water: $94.9 \%$ acetonitrile: $0.1 \%$ formic acid) (Forcat et al. 2008), a flow rate of $0.6 \mathrm{ml} / \mathrm{min}$ with 12 minutes at a wavelength of $250 \mathrm{~nm}$, sample injection of $20 \mu \mathrm{L}$. SA was determined in three independent samples from each sampling and treatment time. The concentration was calculated using a calibration curve with standard salicylic acid. The SA quantification was undertaken using the Agilent 1120 LC chromatography system with a UV detector.

\section{$\beta$-1.3-glucanase activity}

$\beta$-1.3-glucanase activity was determined using Ungara and Seloka-5 which represented resistant and susceptible genotypes to CpnsCK1, respectively, according to the protocol of Wang et al. (2013). Similar to SA estimation, $\beta$-1.3-glucanase activity was done on leaf at different periods after inoculation. The lyophilized leaves $(1.0 \mathrm{~g})$ were ground and homogenized with a $5 \mathrm{ml}$ cold extraction buffer (0.1 M sodium acetate buffer, $\mathrm{pH}$ 5.2). The homogenate leaf was centrifuged at $12000 \mathrm{rpm}$ for 25 minutes, and supernatants used as crude enzyme to be tested its enzyme activity. The reaction mixture consisted of $0.9 \mathrm{ml}$ buffer substrate $(0.1 \mathrm{M}$ sodium acetate buffer, $\mathrm{pH}$ 5.2, laminarin $0.1 \mathrm{mg} / \mathrm{ml}$ buffer) and $0.1 \mathrm{ml}$ enzyme solution (leave extract) was incubated at $37{ }^{\circ} \mathrm{C}$ for 1 hour. Glucanase activity was estimated according to laminarin (glucan) reduction using spectrometer at $540 \mathrm{~nm}$ (Nelson 1994). A $\beta-1.3$-glucanase activity is expressed as $\mu \mathrm{mol}$ glucose equivalent released/g fresh weigh tissue/1 hour.

\section{Molecular characterization based on SCAR Marker}

Genomic DNA was isolated from chilli leaf using cetyl trimethyl ammonium bromide (CTAB) extraction method (Doyle and Doyle 1990) with little modification. The $0.5 \mathrm{~g}$ of leaves were ground in to fine powder in $2 \mathrm{~mL}$ microtube using sterile blue pestle and subsequently to the tube was added $800 \mu \mathrm{L}$ extraction buffer containing $100 \mathrm{mM}$ Tris$\mathrm{HCl}$ (pH 8.0), 1.4 M NaCl, 20 mM EDTA (pH 8.0), cetyl trimethyl ammonium bromide (CTAB) $2 \%$ (w/v), polyvinyl pyrrolidone (PVP) 2\% (w/v), and sodium disulfite $0.38 \%(\mathrm{w} / \mathrm{v})$. The samples were then incubated at $65{ }^{\circ} \mathrm{C}$ for 15 minutes and homogenized. Further, the sample was extracted using $800 \mu \mathrm{L}$ chloroform isoamyl alcohol (24: 1), followed by centrifugation $12,000 \mathrm{rpm}$ for 10 minutes. Supernatant was transferred to $1.5 \mathrm{~mL}$ micro tube, followed by adding 1/10th volumes of $3 \mathrm{M}$ sodium acetate ( $\mathrm{pH}$ 5.2) and 1 volume of chilled isopropanol. The mixture was incubated at $20{ }^{\circ} \mathrm{C}$ for 1 hour, before centrifuged at $12.000 \mathrm{rpm}$ for 10 minutes. DNA pellet was washed with $70 \%(\mathrm{v} / \mathrm{v})$ ethanol and centrifuged again at $12.000 \mathrm{rpm}$ for 5 minutes. Clean pellets were dried and dissolved in $100 \mu \mathrm{L}$ of TE solution (Tris $10 \mathrm{mM}[\mathrm{pH} 8.0]$, EDTA $1 \mathrm{mM}$ ), and added with $2 \mu \mathrm{RNAse} 10 \mathrm{mg} / \mathrm{mL}$. The stock DNA solution was incubated for 1 hour at $37{ }^{\circ} \mathrm{C}$. DNA concentration was quantitatively measured by using a Nanodrop2000 Spectrophotometer (Thermo Scientific TM, United States) to determine absorbance at $260 \mathrm{~nm}$ (Sambrook and Russell 2001) and migrated onto $0.8 \%$ agarose gel. 
Molecular analysis was determined through Polymerase Chain Reaction (PCR) by using a pair of SCAR primers (OpD04,717-F: 5'-CCA TAA GGG TTG GTA AAT TTA CAA AG-3 'and OpD04,717-R: 5'-TCG AGA GAT AAT TCA GAT AGT ATA ATC-3') (Quirin et al. 2005). DNA of each sample was amplified at a total reaction of $10 \mu \mathrm{L}$ containing $2 \mu \mathrm{L}$ of $10 \mathrm{ng} / \mu \mathrm{L}$ DNA template, $5 \mu \mathrm{L}$ MyTaq HS Ready Mix (Bioline, UK), $0.5 \mu \mathrm{L}$ of $10 \mu \mathrm{M}$ forward and reverse primer, and sterile $\mathrm{ddH}_{2} \mathrm{O}$ as remains. The PCR profile was as follows: initial denaturation at $95{ }^{\circ} \mathrm{C}$ for 5 minutes; 35 cycles consisting of denaturation at $94{ }^{\circ} \mathrm{C}$ for 30 seconds, annealing at $45^{\circ} \mathrm{C}$ for 1 minute, and extension at $72{ }^{\circ} \mathrm{C}$ for 1 minute. The final extension was at $72{ }^{\circ} \mathrm{C}$ for 7 minutes. The amplification results were confirmed by electrophoresis in $2 \%$ agarose. The PCR products were then stained using ethidium bromide and visualized on a UV Transilluminator. The scoring system was done based on the presence (+) or absence (-) of bands in each genotype observed. Information from this SCAR profile was confirmed with the profile of the genotypes resistance test in the greenhouse.

\section{RESULTS AND DISCUSSION}

\section{Resistance of chilli genotypes to $\boldsymbol{P}$. capsici isolates}

The inoculation method by drenching zoospore suspension into plant growing media in this study demonstrated its effectiveness which caused wilt and necrotic symptoms on susceptible genotypes. The variance analyses of disease index value showed highly significant difference among genotypes, isolates, and genotypes $\mathrm{x}$ isolates interaction $(P<0.01)$ (Table 1).

$P$. capsici isolates used in this study showed different virulence levels, where WnsbCK2 revealed the highest virulence level, causing death in all chilli genotypes tested. Based on the number of susceptible genotypes, the virulence levels of isolate could be demonstrated on WnsbCK2> WnsbCK1> KdrRM3> CpnsCK1 (Tabel 1, Table 2). The response of chilli genotypes to four $P$. capsici isolates is shown in Table 2. The evaluation of total genotypes using CpnsCK1, WnsbCK1, and KdrRM3 isolates resulted in three groups of resistance, namely resistant (R), moderate resistant (MR), and susceptible (S). Among 41 genotypes against CpnsCK1 isolate resulted in 6 resistant genotypes (Ungara, Violeta, Ayesha, Violeta 1, Sempurna, and Ayesha Ungu), 3 moderate resistant ones (F8 160291-3-12 -5-4-51-1, Rama, and F6 145291-10-7-1$1-1)$, and the remaining reacted susceptible. While, chilli genotypes evaluated against KdrRM3 isolate generated in 2 resistant genotypes (Viola and Tanjung-2), 8 moderate resistant genotypes (Genie, F8 145318-1-1-1-1-3 -1, F8 145291-115-8-1-1, F8 160291-9-4-3-2-1-1, F8 160291-312-5-4-51-1, Vitra, Lingga, and Ungara), and the remaining genotypes were susceptible. Using WnsbCK1, we found one resistant genotype (Nazla), 3 moderate resistant genotypes (Landung, Ungara, and Viola), and 37 susceptible genotypes. It is noted that WnsbCK2 isolate caused all genotypes to react susceptible, suggesting the highest aggressiveness to $C$. annuum.

A number of genotypes had specific interaction with certain isolate of $P$. capsici, indicating there is specific race in this disease response. Ungara, Violeta, Ayesha, Violeta 1, Sempurna, and Ayesha Ungu showed high resistant to CpnsCK1 but moderate to susceptible to another isolate. Viola and Tanjung-2 had specific resistance only to isolate KdrRM3, similarly to Nazla which showed resistance to WnsbCK1 but not to others.

\section{Estimation of SA and $\boldsymbol{\beta}$-1.3-glucanase activity}

Interaction between plant and pathogen has occurred at initial hours after inoculation. This was proven by the different SA content in chili leaves inoculated with $P$. capsici in comparison to uninoculated plant as control (Figure 1).

SA content of plant rose sharply several hours after inoculation of $P$. capsici. In resistant genotype (Ungara), the increase of SA occurred in 3 hours after inoculation with higher SA content than control (without inoculated). At 6 hours, SA content of resistant genotype was decreased but increased in control. On the other hand, in susceptible genotype (Giant A), plants inoculated with $P$. capsici produced lower SA concentration compared to control (without inoculated) and this occurred both 3 and 6 hours after inoculation.

Table 1. Analysis of variance for disease index in chilli genotypes infected by four $P$. capsici isolates

\begin{tabular}{llllll}
\hline Source & $\mathbf{D F}^{\mathbf{a}}$ & Sum of squares & Means square & F value & Pr $>\mathbf{F}^{\mathbf{b}}$ \\
\hline Isolate & 3 & 77755.4 & 25918.5 & 196.9 & $<.0001^{* *}$ \\
Genotype & 40 & 74092.0 & 1852.3 & 14.1 & $<.0001^{* *}$ \\
Isolate x genotype & 120 & 154607.3 & 1288.4 & 9.8 & $<.0001^{* *}$ \\
\multicolumn{7}{l}{} & & & & \\
Genotype x isolate effect sliced by isolate & & Means square & F value & Pr $>\mathbf{F}$ \\
Isolate & $\mathbf{D F}$ & Sum of squares & 2863.5 & 21.8 & $<.0001^{* *}$ \\
CpnsCK1 & 40 & 114542.0 & 1355.7 & 10.3 & $<.0001^{* *}$ \\
KdrRM3 & 40 & 54226.0 & 1408.4 & 10.7 & $<.0001^{* *}$ \\
WnsbCK1 & 40 & 56337.0 & 89.9 & 0.7 & $0.929^{\text {ns }}$ \\
WnsbCK2 & 40 & 3594.6 & &
\end{tabular}

Note: $\mathrm{CV}=14.9 ;$ adf $=$ degrees of freedom; $\mathrm{b} * *=$ Significant at $\mathrm{P}=0.01$ 
Table 2. Disease index (score of 22 days after inoculation) and resistance level of 41 genotypes of $C$. annuum against $P$. capsici

\begin{tabular}{|c|c|c|c|c|c|c|c|c|}
\hline \multirow{2}{*}{ Genotypes } & \multicolumn{2}{|c|}{ CpnsCK1 } & \multicolumn{2}{|c|}{ WnsbCK1 } & \multicolumn{2}{|c|}{ KdrRM3 } & \multicolumn{2}{|c|}{ WnsbCK2 } \\
\hline & DI (\%) & Reaction & DI (\%) & Reaction & DI (\%) & Reaction & DI (\%) & Reaction \\
\hline Ayesha & 4.0 & $\mathrm{R}$ & 92.7 & $\mathrm{~S}$ & 79.3 & $\mathrm{~S}$ & 95.3 & $\mathrm{~S}$ \\
\hline Laris & 90.7 & $\mathrm{~S}$ & 98.0 & $\mathrm{~S}$ & 94.0 & $\mathrm{~S}$ & 100.0 & $\mathrm{~S}$ \\
\hline Bara & 79.3 & $S$ & 94.7 & $S$ & 58.7 & $S$ & 95.3 & $S$ \\
\hline CM334 & 70.7 & $S$ & 96.7 & S & 73.3 & $S$ & 100.0 & $S$ \\
\hline Violeta & 0.0 & $\mathrm{R}$ & 90.7 & $\mathrm{~S}$ & 77.3 & $\mathrm{~S}$ & 100.0 & $\mathrm{~S}$ \\
\hline Lembayung & 70.7 & $S$ & 84.7 & S & 81.3 & $S$ & 100.0 & $\mathrm{~S}$ \\
\hline SSP & 71.3 & $S$ & 94.0 & $S$ & 78.0 & $S$ & 100.0 & $S$ \\
\hline Jalapeno & 75.3 & $S$ & 78.0 & $S$ & 72.7 & $\mathrm{~S}$ & 94.7 & $S$ \\
\hline Genie & 80.7 & $\mathrm{~S}$ & 92.0 & S & 34.7 & MR & 94.7 & $S$ \\
\hline F6 145291-10-7-1-1-1 & 46.7 & MR & 88.0 & $S$ & 54.7 & $\mathrm{~S}$ & 92.7 & $S$ \\
\hline F8 145318-1-1-1-1-3-1 & 94.0 & $\mathrm{~S}$ & 77.3 & S & 48.7 & MR & 100.0 & $S$ \\
\hline F8 145291-115-8-1-1 & 88.7 & $\mathrm{~S}$ & 67.3 & $\mathrm{~S}$ & 25.3 & MR & 93.3 & $\mathrm{~S}$ \\
\hline F8 160291-9-4-3-2-1-1 & 81.3 & $\mathrm{~S}$ & 71.3 & S & 37.3 & MR & 98.7 & S \\
\hline F8 160291-3-12-5-4-51-1 & 44.7 & MR & 80.0 & $\mathrm{~S}$ & 28.0 & MR & 94.7 & $\mathrm{~S}$ \\
\hline Landung & 67.3 & $\mathrm{~S}$ & 36.0 & MR & 70.7 & $\mathrm{~S}$ & 69.3 & $S$ \\
\hline Lokal Lembang & 92.0 & $S$ & 75.3 & $\mathrm{~S}$ & 87.3 & $S$ & 100.0 & $S$ \\
\hline Tanjung-2 & 92.0 & $\mathrm{~S}$ & 89.3 & $\mathrm{~S}$ & 20.0 & $\mathrm{R}$ & 100.0 & $\mathrm{~S}$ \\
\hline Vitra & 77.3 & $S$ & 70.7 & S & 30.7 & MR & 100.0 & $S$ \\
\hline Lingga & 88.0 & S & 98.0 & S & 43.3 & MR & 97.3 & $\mathrm{~S}$ \\
\hline Kencana & 92.7 & $S$ & 88.0 & $S$ & 85.3 & $\mathrm{~S}$ & 100.0 & $\mathrm{~S}$ \\
\hline Cakri Andalas & 92.7 & $S$ & 89.3 & S & 84.7 & $S$ & 100.0 & $S$ \\
\hline Lembang 1 & 89.3 & $S$ & 61.3 & S & 56.7 & $S$ & 96.0 & $\mathrm{~S}$ \\
\hline Ciko & 89.3 & S & 76.0 & S & 72.0 & $S$ & 100.0 & $\mathrm{~S}$ \\
\hline CL-4 & 84.7 & S & 82.7 & S & 59.3 & S & 86.7 & $\mathrm{~S}$ \\
\hline Sempurna & 8.7 & $\mathrm{R}$ & 76.0 & S & 73.3 & S & 96.0 & $S$ \\
\hline Rama & 45.3 & MR & 65.3 & $S$ & 52.0 & S & 94.7 & $S$ \\
\hline Anies & 80.7 & $\mathrm{~S}$ & 67.3 & S & 75.3 & S & 95.3 & S \\
\hline Nazla & 76.0 & S & 13.3 & $\mathrm{R}$ & 60.0 & $S$ & 90.0 & $S$ \\
\hline Seloka-5 & 99.3 & $S$ & 80.7 & $S$ & 79.3 & S & 100.0 & $S$ \\
\hline Yuni & 90.0 & $S$ & 92.0 & $\mathrm{~S}$ & 78.7 & $\mathrm{~S}$ & 100.0 & $\mathrm{~S}$ \\
\hline Ungara & 0.0 & $\mathrm{R}$ & 40.7 & MR & 26.7 & MR & 100.0 & S \\
\hline Viola & 81.3 & $S$ & 41.3 & MR & 16.0 & $\mathrm{R}$ & 99.3 & $S$ \\
\hline Violeta 1 & 6.0 & $\mathrm{R}$ & 68.0 & $\mathrm{~S}$ & 68.7 & $S$ & 100.0 & S \\
\hline Giant A & 100.0 & S & 76.0 & S & 96.0 & $S$ & 100.0 & S \\
\hline $\mathrm{C} 5$ & 88.7 & $S$ & 72.0 & S & 65.3 & S & 99.3 & $\mathrm{~S}$ \\
\hline Ayesha Ungu & 8.7 & $\mathrm{R}$ & 65.3 & S & 74.0 & $S$ & 96.0 & S \\
\hline F5 Syak x 320-202-2-2 & 94.0 & $S$ & 99.3 & S & 76.7 & S & 100.0 & S \\
\hline F5 Syak x 320-202-2-1 & 83.3 & S & 93.3 & S & 74.7 & S & 100.0 & S \\
\hline F5 Syak x 320-201-1-1 & 86.0 & $S$ & 95.3 & S & 60.7 & $S$ & 100.0 & $S$ \\
\hline Ayesha 2 & 100.0 & $S$ & 97.3 & $S$ & 75.3 & $S$ & 100.0 & $S$ \\
\hline Namira & 100.0 & $\mathrm{~S}$ & 99.3 & $\mathrm{~S}$ & 80.0 & $S$ & 100.0 & $S$ \\
\hline & $P<0.01 * *$ & & $P<0.01 * *$ & & $P<0.01 * *$ & & $P<0.01 * *$ & \\
\hline
\end{tabular}

Note: $\mathrm{DI}=$ disease index, $* *=$ Significant at $P=0.01 . \mathrm{R}=$ Resistance $(\mathrm{DI} \leq 20) ; \mathrm{MR}=$ moderate resistance $(20<\mathrm{DI}>50) ; \mathrm{S}=$ susceptible (DI>50) (Jo et al. 2014)
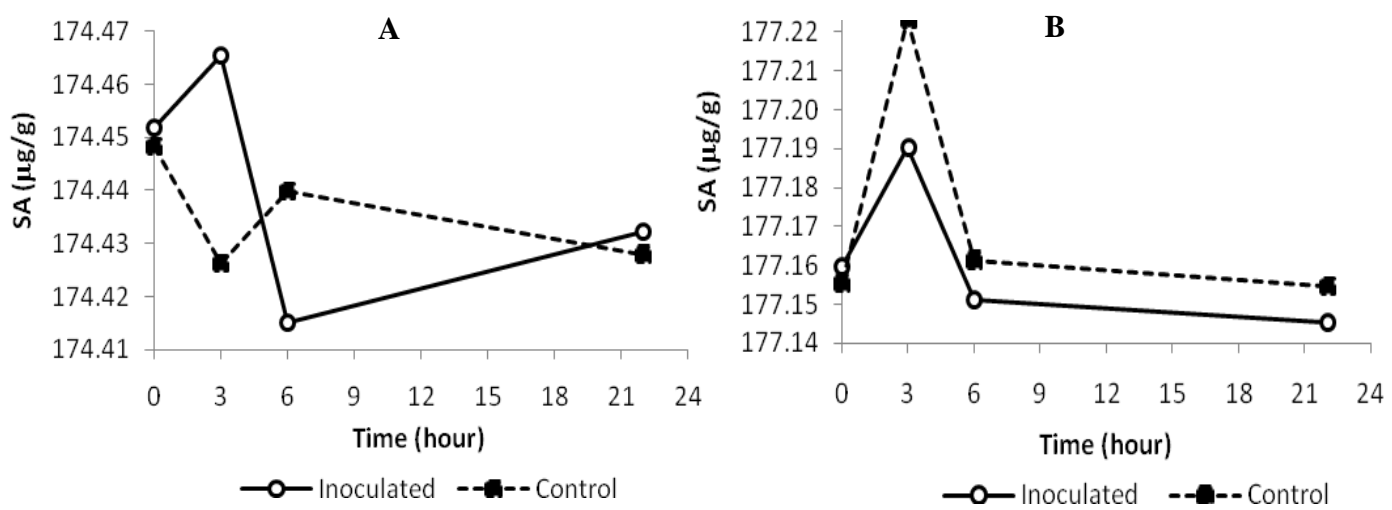

Figure 1. SA production in leaf of chilli genotypes: A. Ungara; B. Giant A 
$\beta$-1.3-glucanase activities were measured in the leave extract both from plants inoculated with the $P$. capsici and control (Figure 2). The activity of $\beta$-1.3-glucanase of resistant genotype (Ungara) increased after $P$. capsici inoculation compared to control plant. The maximum accumulation of the $\beta-1.3$-glucanase activity was detected at $3 \mathrm{~h}$ after inoculation. Whereas in susceptible genotype (Seloka-5), $\beta$-1.3-glucanase activities of $P$. capsici inoculated plants were lower than control at 3 and $5 \mathrm{~h}$ after inoculation. At $7 \mathrm{~h}$ after inoculation, $\beta$-1.3-glucanase activity of Ungara showed a decrease and the $\beta-1.3-$ glucanase activity of inoculated plants was still higher than control. For Seloka-5, $\beta$-1.3-glucanase activity also showed a decrease, but different with that at 3 and $5 \mathrm{~h}$ after inoculation, the $\beta$-1.3-glucanase activity at $7 \mathrm{~h}$ after inoculation was higher than control.

\section{Resistance evaluation using SCAR marker}

SCAR analysis was performed to expectedly complement disease index. Amplicons produced by primer OpD04,717-F/OpD04,717-R was 700 bp, as described in Figure 3. This size of PCR product in this study is consistent with the previous research (Quirin et al. 2005). Besides CM334, the chilli genotype used to develop the SCAR marker (Quirin et al. 2005), the marker also appeared on another 14 chilli genotypes. The amplicons were not only detected in Tanjung-2 and Sempurna, which were previously known as resistant genotypes, but also appeared on susceptible genotypes (Laris, SSP, F8 1602913-12-5-4-51-1, Lokal Lembang, Vitra, Lingga, Kencana, Andalas Cakri, Anies, Yuni, Giant A, and C5). Conversely, the amplicons of this SCAR marker did not appear on Viola and Nazla that were identified to be resistant to KdrRM3 and WnsbCK1, respectively.

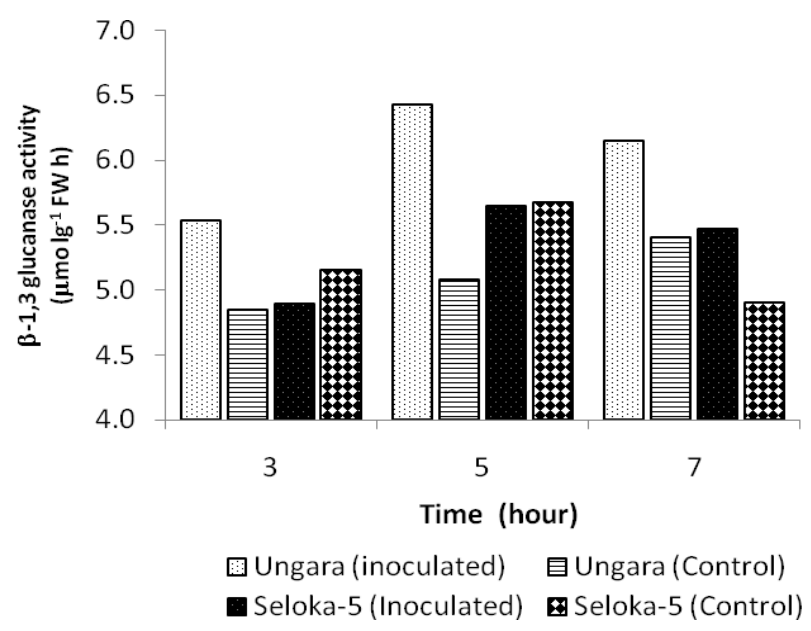

Figure 2. $\beta$-1.3- Glucanase activity of chilli genotypes
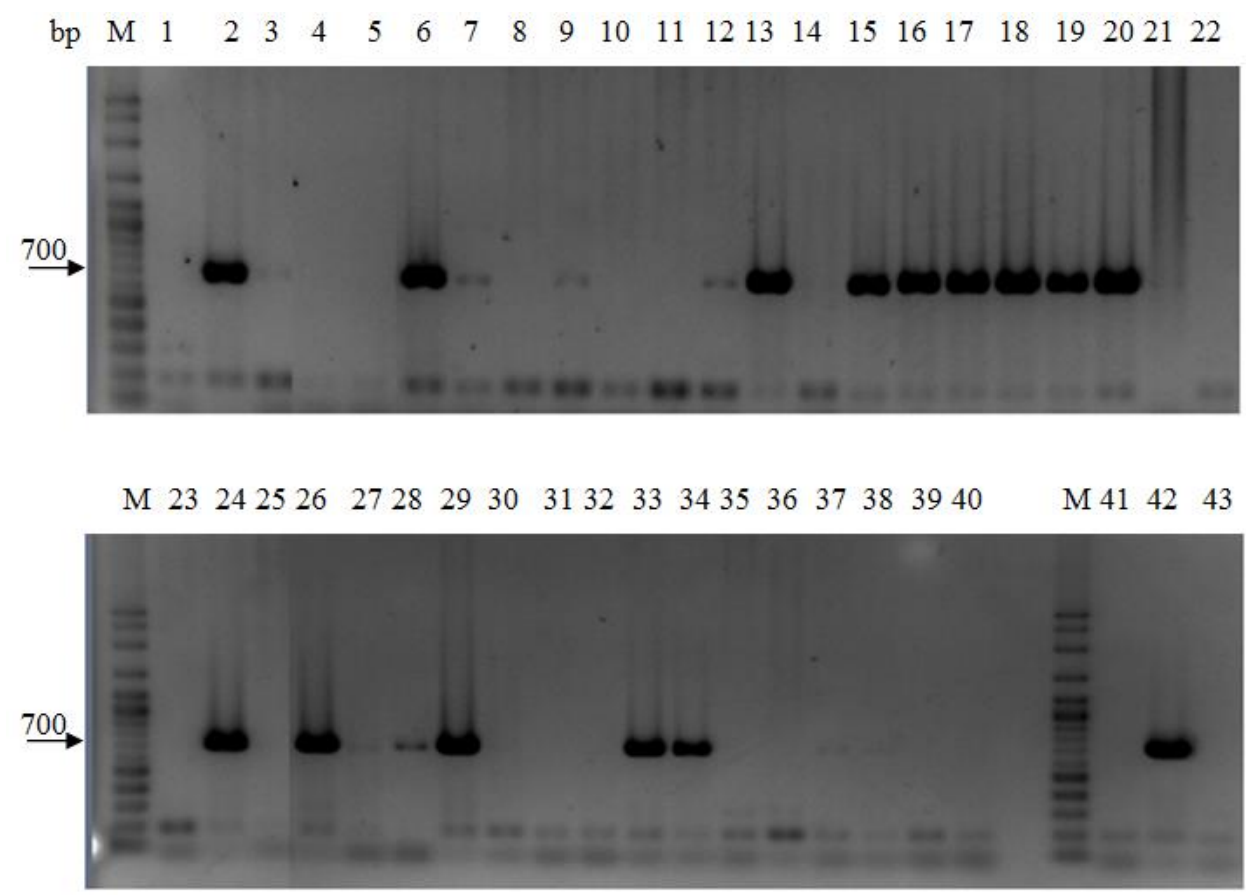

Figure 3. DNA banding pattern of of C. annuum genotypes produced by SCAR primer pair of OpD04.717-F/OpD04.717-R. M) 100 bp DNA ladder, 1. Ayesha, 2. Laris, 3. Bara, 4. Violeta, 5. Lembayung, 6. SSP, 7. Jalapeno, 8. Genie, 9. F6 145291-10-7-1-1-1, 10. F8 145318-1-1-1-1-3-1, 11. F8 145291-115-8-1-1, 12. F8 160291-9-4-3-2-1-1, 13. F8 160291-3-12-5-4-51-1, 14. Landung, 15. Lokal Lembang, 16. Tanjung-2, 17. Vitra, 18. Lingga, 19. Kencana, 20. Cakri Andalas, 21. Lembang 1, 22. Ciko, 23. CL-4, 24. Sempurna, 25. Rama, 26. Anies, 27. Nazla, 28. Seloka-5, 29. Yuni, 30. Ungara, 31. Viola, 32. Violeta 1, 33. Giant A, 34. C5, 35. Ayesha Ungu, 36. Bara, 37. Genie, 38. F5 Syak x 320-202-2-2, 39. F5 Syak x 320-202-2-1, 40. F5 Syak x 320-201-1-1, 41. Ayesha 2, 42. CM334, 43. Namira 


\section{Discussion}

Although the measurement of disease scoring of plant caused by pathogen naturally infecting in field conditions is reliable, to be exposed to pathogens evenly and achieve uniform infection is not always possible. Homogeneous infection is important to identify the susceptibility of plant. For this reason, we used a standardized infection in our study as done by Bosland and Lindsey (1991) to evaluate resistance of chilli genotype in greenhouse condition. Drenching to growing medium allowed the inoculum load per plant to be controlled and minimized plants escaping infection and consequently, a false response to pathogens can be avoided. In addition, the age uniformity of seedlings used in this research can avoid miss assessment of resistance. According to Kim and Hwang (1989), the plant with different age would show different resistance

$P$. capsici is a pathogen that has high genetic diversity, wide host range, different virulence, and various race (Kim and Hwang 1992; Hausbeck and Lamour 2004; Li et al. 2012). Virulence levels in this pathogen are useful for selecting chilli genotypes resistance. The four isolates employed in this study showed different virulence levels, according to resistance response of chilli genotypes. In this research, we found that isolate WnsbCK2 derived from Wonosobo had the highest virulence level causing 41 tested chilli genotypes to be susceptible. Whereas, the three other isolates, WnsbCk1, CpnsCK1, and KdrRM3, had moderate virulence level which caused several chilli genotypes to react resistance, moderate resistance, and susceptible. Generally, the virulence level of $P$. capsici consists of three groups, namely low, medium and high, where the virulence level depends on their pathogenicity to certain hosts (Silvar et al. 2006; Granke et al. 2012), and their ability to cause disease in varieties/lines/genotypes that were previously resistant. Similar variation in virulence was demonstrated among isolates of $P$. capsici originating from different geographical based on pathogenicity tests through drenching of inoculum on growing medium (Jiang et al. 2015).

Due to virulence and race variations in $P$. capsici, then developing resistant varieties is important. Chilli genotypes used in this research showed diverse responses to $P$. capsici isolates. Among 41 tested chilli genotypes, six genotypes were resistant to isolate CpnsCK1, two genotypes were resistant to KdrRM3, and one genotype was resistant to WnsbCK1, whereas none of genotypes used in this study had resistance to the high virulence isolate, WnsbCK2. Resistance to certain isolates indicated that the resistance of genotypes is specific isolate. There are strong indications of the existence of specificity between $P$. capsici isolates and chilli genotypes for partial resistance. The effect of genotype $\times$ isolate interaction sliced by isolate allows individual interactions to be clearly identified. Chilli genotypes of Ungara, Violeta, Ayesha, Violeta 1, Sempurna, and Ayesha Ungu had specific resistance to CpnsCK1. While, Viola and Tanjung-2 have specific resistance to KdrRM3 while Nazla to WnsbCK1. This result is in accordance with previous research which tested the resistance of several chilli cultivars to different isolates of $P$. capsici from different country (Hwang, et al. 1996).
The resistance of chilli genotypes to certain isolate was probably controlled by monogenic and it likely occurs due to gene-for-gene relationship, where the resistance gene of chilli genotype can recognize avirulent gene of pathogen.

Resistance of chilli genotypes to $P$. capsici is related to changes in salicylic acid (SA) concentration. It has been known since a few years ago that SA is an important signal in systemic acquired resistance (SAR) which is associated with the expression of a set of so-called SAR genes, which include some of PR genes. (Dempsey et al. 1999). This event was also shown by the changes in SA concentration in Ungara genotype, where its SA concentration rose after being inoculated by $P$. capsici. Typically, increased SA indicates that this induced resistance system as systemic acquired resistance (SAR), which is effective against pathogen, including fungi, bacteria, and viruses (Ryals et al. 1996). SA is a mobile signal for plant resistance to pathogens, in which increased SA causes plants to become more resistant to pathogens (Smith-Becker et al. 1998; Verberne et al. 2000).

This study revealed that $\beta$-1.3-glucanase of Ungara genotype increased linearly following SA increase. This is relevant to the results of the other research that reported the relationship between endogenous-SA increase in chilli with activation of the resistance component and the induction of pathogenesis-related protein, $\beta$-1.3-glucanase (Hwang et al. 1992).

The use of markers can speed up the selection process without inoculating pathogens which require more time. In previous studies, it was known that one of the quantitative trait locus (QTL) associated with chilli resistance to $P$. capsici was QTL Phyto 5.2 which was found on chromosome 5 (Quirin et al. 2005; Truong et al. 2012). Sequence characterized amplified region (SCAR) markers linked with this chromosome succeeded in distinguishing susceptible genotypes from resistant chilli (Quirin et al. 2005). However, their research did not reveal the type of race and the origin of $P$. capsici isolates used as a standard for evaluation. In this study, the SCAR marker developed by Quirin et al. (2005) was applied to evaluate the resistance of Indonesian chilli genotypes, those which were inoculated by four different isolates of $P$. capsici originating from chilli plant in Java island. The result showed that the SCAR marker did not appear in chilli genotypes reacting resistant, but instead appeared in genotypes with susceptible reaction. For example, resistance markers were not seen in the Ungara cultivar which was resistant to isolate CpnsCK1, instead, the marker appeared on the Yuni cultivar which was susceptible to all $P$. capsici isolates. This result suggested that SCAR marker used in this study has not been able to explain the differences of resistance of chilli genotypes inoculated by different $P$. capsici. This means that the chilli genotypes reacting resistant to isolates from Java are probably controlled by another locus that is not detected by this SCAR marker. It shows that probably the resistance is not only controlled by genes in the certain chromosome in the core, but also controlled by the multitude of variants throughout the genome (Barchenger, et al. 2018). According to Barchenger, et al. (2018), it has been 
identified that no loci would cause resistance to chilli over a wide geographical area or different genetic backgrounds. Therefore, other markers are still needed to distinguish resistance of chilli genotypes. Moreover, we should not only study core genes and pathways, but also the multitude of variants throughout the genome that have seemingly small effects on resistance.

\section{ACKNOWLEDGEMENTS}

This research was supported by Ministry of Research, Technology and Higher Education of the Republic of Indonesia who has funded this research through an applied grant in 2019 and routine budget from Indonesian Center for Agricultural Biotechnology and Genetic Resources Research and Development, Indonesian Agency for Agricultural Research and Development under Ministry of Agriculture, Republic of Indonesia.

\section{REFERENCES}

Abdin MZ, Mirza KJ, Khan S, Kiran U, Ram M et al. 2012. Development and detection efficiency of SCAR markers of Cuscuta reflexa and its adulterant Cuscuta chinensis. J Food Drug Anal 20: 471-477.

Barchenger DW, Lamour KH, Bosland PW. 2018. Challenges and strategies for breeding resistance in Capsicum anпиum to the multifarious pathogen, Phytophthora capsici. Front Plant Sci 9 (628): $1-16$.

Bosland P, Lindsey D. 1991. A seedling screen for Phytophthora root rot of pepper, Capsicum annuum. Plant Dis 75: 1048-1050.

Café-Filho AC, Ristaino JB. 2008. Fitness of isolates of Phytophthora capsici resistant to mefenoxam from squash and pepper fields in North Carolina. Plant Dis 92: 1439-1443.

Candole BL, Conner PJ, Ji P. 2010. Screening Capsicum annuиm accessions for resistance to six isolates of Phytophthora capsici HortScience 45: 254-259.

Da Silva GF, Dos Santos JB, Ramalho MAP. 2003. Identification of SSR and RAPD markers linked to a resistance allele for angular leaf spot in the common bean (Phaseolus vulgaris) line ESAL 550. Genet Mol Biol 26 (4): 459-463.

Dempsey DA, Shah J, Klessig DF. 1999. Salicylic acid and disease resistance in plants. Crit Rev Plant Sci 18 (4): 547-575.

Direktorat Jendral Hortikultura. 2019. Data produksi sayuran. Accepted from: http: //hortikultura2.pertanian.go.id [Indonesian]

Doyle JJ, Doyle JL. 1990. Isolation of plant DNA from fresh tissue. Focus $12,13-15$.

Forcat S, Bennett HM, Mansfield WJ, Grant MR. 2008. A rapid and robust method for simultaneously measuring change in the phytohormones ABA, JA and SA in plants following biotic and abiotic stress. Plant Methods 4: 16.

Glosier BR, Ogundiwin EA, . Sidhu GS, Sischo DR, Prince JP. 2008. A differential series of pepper (Capsicum апnиит) lines delineates fourteen physiological races of Phytophthora capsici. Euphytica 162: 23-30.

González-Gallegos E, Laredo-Alcalá E, Ascacio-Valdés J, Jasso de Rodríguez D, Hernández-Castillo FD. 2015. Changes in the production of salicylic and jasmonic acid in potato plants (Solanum tuberosum) as response to foliar application of biotic and abiotic inductors. Am J Plant Sci 6: 1785-1791.

Granke LL, Quesada-Ocampo LM, Hausbeck MK. 2012. Differences in virulence of Phytophthora capsici isolates from a worldwide collection on host fruits. Eur. J. Plant Pathol 132: 281-296.

Hausbeck MK, Lamour KH. 2004. Phytophthora capsici on vegetable crops: research progress and management challenges. Plant Dis 88 (12): 1292-1303.

Hwang BK, Sunwoo JY, Kim YJ, Kim BS. 1992. Accumulation of $\beta$-1.3glucanase and chitinase isoforms, and salicylic acid in the DL-b- amino-n-butyric acid-induced resistance response of pepper stems to Phytophthora capsici. Physiol Mol Plant Pathol 51: 305-322.

Hwang BK, Kim YJ, Kim CH. 1996. Differential interactions of Phytophthora capsici isolates with pepper genotypes at various plant growth stages. Eur J Plant Pathol 102: 311-316.

Jiang L, Sanogo S, Boslan PW. 2015. Using recombinant inbred lines to monitor changes in the race structure of Phytophthora capsici in chili pepper in Mexico. Plant Health Progr 16 (4): 235-240.

Jo SJ, Shim SA, Jang KS, Choi YH, Kim JC, Choi JG. 2014. Resistance of chili pepper cultivars to isolates of Phytophthora capsici. Kor J Hort Sci Technol 32 (1): 66-76.

Kamaluddin, Khan MA, Khan MA, Alam P, Ahmed S , Abdin MZ, Khan MN, Bhatt MA. 2014.Genetic diversity analysis and development of SCAR marker associated with stripe rust resistance in spring wheat (Triticum aestivum L. em Thell). Indian J Biotechnol 13: 9-18.

Kim ES, Hwang BK. 1992. Virulence to Korean pepper cultivars of isolates of Phytophthora capsici from different geographic areas. Plant Dis 76: 486-489.

Kim YJ, Hwang BK, Park KW. 1989. Expression of age-related resistance in pepper plants infected with Phytophthora capsici. Plant Dis 73: 745-747.

Kiran I, Mirza KJ, Khan S, Ram M, Abidin MZ. 2010. SCAR markers: A potential tool for authentication of herbal drugs. Fitoterpia 81: 969976.

Lamour KH, Stam R, Jupe J, Huitema E. 2012. The oomycete broad hostrange pathogen Phytophthora capsici. Mol Plant Pathol 13: 329-337.

Li P, Cao S, Dai YL, Li XL, Xu DF, Guo M, Pan YM, Gao ZM. 2012. (Pythiaceae) isolates in Anhui Province of China based on ISSR-PCR markers. Genet Mol Res 11 (4): 4285-4296.

Oelke LM, Steiner R, Bosland PW. 2003. Differentiation of race-specific resistance to Phytophthora root rot and foliar blight in Capsicum аппиит. J Am Soc Hortic Sci 128: 213-218.

Ovesná J, Poláková K, Leišová L. 2002. DNA analysis and their applications in plant breeding. Czech J Genet Pl Breed 38 (1): 29-40.

Quirin EA, Ogundiwin EA, Prince JP, Mazourek M, Briggs MO, Chlanda TS, Kim KT, Falise M, Kang BC, Jahn MM. 2005. Development of sequence characterized amplified region (SCAR) primers for the detection of Phyto.5.2, a major QTL for resistance to Phytophthora capsici Leon. in pepper. Theor Appl Genet 110: 605-612.

Ryals JA, Neuenschwander UH, Willits MG, Molina A, Steiner HY, Hunt MD. 1996. Systemic acquired resistance. Plant Cell 8: 1809-1819.

Sambrook J, Russell DW. 2001. Molecular Cloning: A Laboratory Manual, Cold Spring Harbor Laboratory Press, New York.

Silvar C, Merino F, Díaz J. 2006. Diversity of Phytophthora capsici in northwest Spain: Analysis of virulence, metalaxyl response, and molecular characterization. Plant Dis 90: 1135-1142.

Smith-Becker J, Marois E, Huguet EJ, Midland SL, Sims JJ, Keen NT. 1998. Accumulation of salicylic acid and 4-hydroxybenzoic acid in phloem fluids of cucumber during systemic acquired resistance is preceded by a transient increase in phenylalanine ammonia-lyase activity in petioles and stems. Plant Physiol 116: 231-238.

Sy O, Steiner R, Bosland PW. 2008. Recombinant Inbred Line Differential Identifies Race-Specific Resistance to Phytophthora Root Rot in Capsicum annuum. Phytopathology 98 (8): 867-870.

Syukur M, Sujiprihati S, Yunianti R, Nida K. 2010b. The estimation of variance component, heritability, and correlation to determine selection criteria in the F5 population of pepper (Capsicum аппиит L.). J Hort Indonesia 1: 74-80.

Syukur M, Sujiprihati S, Yunianti R, Kusumah D.A. 2011. Estimation of genetic variance and heritability for yield component characters in chili pepper genotypes. J Agrivigor 10: 148-156.

Syukur M, Sujiprihati S, Yunianti R, Kusumah DA. 2010a. Yield evaluation of pepper hybrids and their adaptation at four locations in two years. Jurnal Agronomi Indonesia 38 (1): 43-51.

Truong HTH, Kim KT, Kim DW, Kim S, Chae Y, Park JH, Oh DG, Cho MC. 2012. Identification of isolate specific resistance to Phytophthora root rot in pepper (Capsicum aпnиum L.). Plant Pathol 61: 48-56.

Verberne MC, Verpoorte R, Bol JF, Mercado-Blanco J, Linthorst HJM. 2000. Overproduction of salicylic acid in plants by bacterial transgenes enhances pathogen resistance. Nature Biotech 18: 779-783.

Wang JE, Li DW, Zhang YL, Zhao Q, He YM, Gong ZH. 2013. Defense responses of pepper (Capsicum аппиит L.) infected with incompatible and compatible strains of Phytophthora capsici. Eur J Plant Pathol 136: 625-638. 